\title{
ЛИТЕРАРНО-ДОКУМЕНТАРНА ПРОЗА У НАСТАВИ ЗАВИЧАЈНЕ КУЛТУРЕ: НА ПРИМЕРУ ПИСАЦА ИЗ УЖИЦА
}

\begin{abstract}
У раду се разматра образовни потенцијал литерарно-документарне прозе писаца који су рођени у Ужицу, а живели су у другој половини 19. и првој половини 20. века. Циљ је да се испитају могућности унапређивања ученичких компетенција применом ових дела у настави завичајне културе. Анализа је показала да литерарно-документарна проза завичајних писаца представља наратив богат подацима и детаљима, који наставнику омогућавају да из различитих перспектива осветли догађаје, личности и појаве. Фактографска подлога ове прозе, у комбинацији са сликовитим описима и живописним причама, помаже ученику да оживи догађаје у својој свести. Закључује се да литерарно-документарну завичајну прозу треба користити у настави завичајне културе: (1) за унапређивање вештина читања и разумевања; (2) за упознавање завичајне историје, као и улоге завичајних личности и догађаја у националној историји; (3) за стицање представа о начину на који се одвијао приватни живот (породица, школа и сл.). На овај начин код ученика се развија свест о припадности одређеној заједници и жеља да се личним деловањем допринесе очувању завичајне културне баштине.
\end{abstract}

Кључне речи: литерарно-документарна проза, настава српског језика и књижевности, настава историје, образовни потенцијал, завичајна културна баштина.

\section{Увод}

Како се указује у методичкој литератури, задаци савременог образовања јесу: (а) да припреми ученика за живот у мултикултуралним свету у коме постоји дијалог између различитих култура; (б) да изгради код ученика свест о припадности одређеној заједници и жељу да се личним деловањем допринесе очувању њених духовних и материјалних добара (Елез, 2012: 13; Николић, Вељовић, 2018: 125). Сматра се да ће дете које је свесно идентитета своје уже средине моћи да са изоштренијим критеријумима прихвата

\footnotetext{
${ }^{1}$ milkanik75@gmail.com

${ }^{2}$ Овај рад написан је у оквиру пројекта Динамика структура савременог српског језика (2011-2020), број 178014, који финансира Министарство науке и просвете Републике Србије.
} 
тековине опште културе, као и појединачних других култура (Тежак, 1980: $155)$.

Завичај представља емоционалну, књижевну, педагошку и дидактичко-методичку категорију (Урошевић, Урошевић Хушак, 2012: 128). „У богатству, особености и снази завичајног народног говора, језика, усменог ставралаштва, фолклора, пејзажа, друштвено-економске, социоетничке, понекад психоменталне структуре и читаве баштине - налазе се непресушна изворишта, подстицаји и надахнућа за књижевноуметничку реч и ликовност, за завичајни филм, фотографију и стваралаштво уопште“ (Цветковић, 2011: 262).

У овом раду разматра се образовни потенцијал изабраних дела литерарно-документарне прозе аутора различитог профила (занатлије, трговци, уметници), који су рођени у Ужицу, а живели су у другој половини 19. и првој половини 20. века. Циљ је да се испитају могућности унапређивања ученичких компетенција применом одломака завичајне литерарно-документарне прозе. ${ }^{3}$ Очекивано је да обрада текстова завичајне къижевносmи може да допринесе: (а) упознавању завичајне баштине и изграђивању завичајног идентитета; (б) јачању трансферних и генеративних знања из различитих наставних предмета и области (српски језик, књижевност и историја).

\section{Образовни потенцијал завичајне литерарно-документарне прозе ужичких писаца}

Литерарно-документарна проза има значајан образовни потенцијал јер омогућава ученицима: (а) да свестраније упознају личности уметника и научника, као и да разумеју њихова стваралачка опредељења; (б) да запазе и да схвате важност изграђивања националног и културног идентитета (в. Костић, 2012: 450, 455). Жанрови овог типа прозе - дневници, аутобиографије и мемоари - представљају погодне текстове за обраду у настави српског језика и књижевности захваљујући „двострукој читљивости” којом се одликују ова остварења (в. Стефановић, 2010: 6-7). Наиме, у текстовима тзв. мешовитих (књижевно-научних) жанрова интерферирају фактографија и фикција тако да се они могу читати и као „историјско сведочанство” и као „књижевно дело”.

Аутор литерарно-документарне прозе примењује механизме селекције, редукције, интеграције и интерпретације чињеница из сопственог живота, као и чињеница везаних за историју уже и шире заједнице. „Аутобиографски текстови се тако указују као паралелни живот, као знаци културе,

\footnotetext{
${ }^{3}$ Припадност одређеног текста завичајној култури (завичајној књижевности) одређује се према (1) тематици текста или према (2) родном крају аутора (Бењак, Љубешић, 2013: 19).
} 
као присутна одсутност, као залажење у пределе поетског и документарног, као залога истинитог и могућег, па се у зависности од ових параметара могу проучавати са аспекта културе (као знаци културе), из перспективе онтологије (као знак конституисања живог бића) или у складу са поетичким намерама ствараоца (као знак илузије стварности и уверљивости, као знак истинитог, као знак везивања књижевног текста за стварност, као знак документарног)" (Јоковић, 1998: 462).

Према препорукама које даје методичка литература, избор завичајних текстова за наставу заснива се на следећим параметрима: (1) уметничка вредност; (2) интересантна тематика; (3) језичко-стилска изражајност; (4) психолошка, етичка и идејна примереност узрасту ученика; (5) васпитна адекватност (уп. Скок, 1975; Николић, Вељовић, 2018). Обраду завичајних литерарно-документарних текстова треба усмерити према општим циљевима савремене наставе: (1) развијање вештина прикупљања, анализе и евалуације података; (2) подстицање ученика да се баве интелектуалним радом; (3) развијање креативности; (4) изграђивање умења за спровођење једноставнијих истраживања; (5) оспособљавање за трансфер знања из различитих области; (6) формирање вредносног система заснованог на јачању сопственог и уважавању туђег идентитета (уп. Вељовић, 2018: 510).

У овом раду размотрићемо три жанровски различита примера литерарно-документарне завичајне прозе ужичких писаца која се могу применити у настави српског језика и историје (на различитим узрастима ученика): (а) Миладин Радовић - мемоари; (б) Марија Мага Магазиновић - аутобиографија; (в) Борисав Малиша Атанацковић - дневник.

Миладин Радовић (1852-1915) у мемоарима, постхумно објављеним под називом Самоуки рукопис, предочава догађаје који су обележили историју Ужица и Србије у другој половини 19. и почетком 20. века. ${ }^{4}$ Обухваћени су догађаји од одласка Турака из Ужица 1868. године до почетка Првог светског рата, с тим што се помињу и историјски детаљи из прве половине 19. века. Миладин Радовић није био школован (научио је самостално да чита и пише док се припремао за пекарски занат). Учествовао је у друштвено-политичком животу ужичког краја и објављивао разноврсне текстове у часописима. Из његових мемоара за наставу је погодан одломак о уређењу Ужица, који сведочи да прегалаштво појединца може да буде далекосежније него залагање читаве заједнице:

Ристо Тешић, сајџија обрати се општинскои управи и саопшти јој да се против воде, која у варош за време кише увлачи крш и камен, мора озбиљна повести брига и да та ругоба мора да се спречи. [Пошто општина није уважила његов предлог] он се реши да почне сам колико може и зна. Образује један мали одбор и са њиме почне пошумљавати она мјеста одакле је највећа опас-

\footnotetext{
${ }^{4}$ О животу, друштвеној активности и стваралаштву Миладина Радовића постоје малобројна истраживања (уп. Радовић, 2006; Николић, 2019).
} 
ност била и једва умоли општинску управу да му даде понекога кулучара. [...] Онај Парк према Жељезничкој станици он је подиго. А знате ли како је било пре? Усред пола дана туда нико није пролазио. Ту су сваки дан долетале каменице озго из брда, нешто саме, а нешто козе отискивале. Онде су извлачили из вароши стрвине. Онде је извођена заражена стока те убијата. Једном је онде убивено око дваес шапљиви волова. То се звало коњско гробље. Но Ристо од купатила [која је претходно саградио у околини града] начини воденице и од целокупног прикода начини Парк, пошуми сва брда и потоке, погради путеве, начини воденице и купатила и рибњак у Парку. Једном речи, створи од пустиње башчу без паре да кошта општину, осим нешто кулучара (Радовић, Мемоари: 127-128).

Претходни пример упознаје ученике са начином на који је њихов град добио првобитно модерно урбано уређење, а прича уједно има и васпитну вредност. И следећи одломак има наглашену поучну компоненту, која представља својеврсни интегративни фактор Радовићевих мемоара на макроплану:

[...] Једног љета била је јака суша. Три мјесеца није падала киша у селу Маковишту и један човек, коме сам име заборвио, а виђо сам га, гледајући како неће имати ништа у кућу унијети, наљути се и на бога и на све па узме пушку, напуни је, изађе пред кућу и уз велику псовку окрене пушку на сунце, снишани и гађа право пут сунца, вичући:

- Ти мене ове године све изгоре.

Гађо је у оној љутњи три пута. То је било љети.

Дан по дан дошо је и Божић. Спремио је и он за празник пецивицу. Кад је дошло време ручку, била је тишина - обичан зимски дан. Он оде у подрум под кућом да осијече пецивице. Таман је он почо сећи, а дуну неки ветар и он се нађе на равни. У који је ма ветар дуно, он му је смако кућу са подрума и однио на двеста метара дањине са свима чељадима и са стварима. И ветра нестаде. Кад је тамо дошо, чељад изгрувата и престрашљена. Једне му девојчице од 12-13 година нема. Тражили су је и тражили и никад је нису нашли ни мртву ни живу. [...]

Откуд вјетар само њему кад га у околини тога дана није било, кад у околини ни једна шиша валила и нико није осетио тога дана вјетра. [...] Зар то није божја казна? Људи не могу да казне као бог (Радовић, Мемоари: 54-55).

Марија Мага Магазиновић (1882-1968) на почетку аутобиографије Moj живот показује како је изгледао градски, породични и школски живот у Ужицу крајем 19. века (други део аутобиографије односи се на њен живот после пресељења њене породице у Београд 1896. године). ${ }^{5}$ Мага Магазиновић има значајно место у култури ужичког краја и у националној култури. Као што је познато, била је балерина, новинар, преводилац, писац књижевних текстова, аутор стручних текстова из педагогије, као и претеча аван-

\footnotetext{
${ }^{5} \mathrm{O}$ школовању, уметничком, публицистичком и педагошком раду Марије Маге Магазивић постоји више истраживања (уп. Корићанац, 2000; Костић, 2014; Николић, 20206).
} 
гардних уметничких покрета на почетку 20. века. Наредни пример из њене аутобиграфије доноси интересантне детаље о томе како су се у ужичком крају гајиле свилене бубе и како се у домаћој радиности производила свила:

Гајила је [мајка] кроз више година свилне бубе. Дудова је било доста у Рајићевој и дединој кући. Чинило нам је задовољство да беремо лишће и хранимо бубе, иако у њиховој соби није баш најпријатније мирисало. Кад грицкају, то је шуштало као кад пада киша. А тек кад се стану завијати у красне беле или жуте чаурице. [...] Известан број био је намењен ,за семе”. Оне би се брижљиво справљале и чувале. А кад из њих излете лептири, остајале би у њима ружне мрке рупе. Остале чауре стављале су мама и тетка у врућу воду или у сито над пару, те су чистим дрвцетом поткачиле конце од извесног броја чаурица. Тако су на мотовило снурале тање и дебље свилене конце, некад и на лакат, те добијале кануре од свиле, беле или жуте, или шампањ боје. То није било лако гледати, пошто су луткице у чаурама од топлоте морале угинути, те су их, пошто се свила скине, бацали да их живина зобље. Нама их је било тако жао. Свила се потом искувавала у сапуници, добијала мекоту и сјај, те била припремљена за ткање платна „свилењака” (Магазиновић, Аутобиографија: $100)$.

Одломци у којима Мага Магазиновић говори о свом школовању у Српској краљевској реалки сведоче о тежњама ужичких грађана тог времена да иду у корак с модерним европским образовањем и модерним начином живота:

Физику нам је предавао Г. Теофановић, јако оригинална изгледа и он и његова госпођа, од које се одвајао само за време школских часова. Обоје су се за ондашњу паланку носили врло необично. Он у реденготу цимет или грао боје, док су остали професори носили тамне жакете, браон или тегет. И шешир му је био друкчије фазониран него у осталих грађана [...]. Машна му је такође била нарочита, неке пастел боје. Госпођа је свако предвече ишла с њим испод руке. Одевена у „кринолин” с безброј машни, волана, плетеница на сукњама [...]. Одакле су они запали у Ужице - није ми било познато. Да ли из Чешке, из Аустрије? [...]

Предавао је он такође необично. Одмерено, некако уљудно а зналачки, убедљиво и занимљиво. Све физичке законе објашњавао нам је изврсно и формуле су нам постајале одмах јасне. У ІІІ разреду смо се служили уџбеником Гановим, управо прописаним за више разреде. Нама је то јако импоновало. Одушевљено смо радили у III и IV разреду из математике степеновање, кореновање и логоритмовање те нам ипак математичко знање није потпуно достизало висину коју наш уџбеник из физике захтева. Али нам је он све умео упростити и учинити доступним (Магазиновић, Аутобиографија: 78-79).

Борисав Малиша Атанацковић (1860-1919), ужички трговац и предузетник, пише дневник током Првог светског рада путујући по Еворпи као члан избегличке државне делегације (према датумима у дневнику, обух- 
ваћен је период од августа 1915. до јануара 1919. године). ${ }^{6}$ Ово дело има и завичајни и интеркултурални образовни потенцијал јер показује Атанацковићево поштовње према европској култури и његово настојање да вредности и достигнућа европских земаља пренесе у свој завичај (путеви, железница, хидроцентрала, улично осветљење, пољопривреда, индустрија, грађевинарство, шумарство и сл.). Завичајну и интеркултуралну компоненту има следећи одломак:

15. мај 2016. године. - Јуче у два сата пошао сам из Нице, овде [у месту Екс] сам био у пола седам сати увече. [...] Екс је лепа варош, мирна, без велике ларме, изгледа чисто школска варош. И овде се види да су Франузи много полагали увек на путеве, јер од Марсеља до Екса куд год погледаш путеви као длан, све је то насуто шодером и песком, па утврђено добро тешким ваљком тако да се лако не може ни изровити ни покварити. Нису жалили ни материјала ни икаквих средстава, да кад се пут прави да се направи како ваља. [...] Како је са путевима среским, сеоским и окружним, тако је и са железничким пругама. Ама и оне се праве тако стабилно и јако да ти је милина погледати. Чини ми се да се у почетку кад се раде, предвиде све евентуалности и све елементарне непогоде које би могле наступити, па се при првом раду отклоне, да после не могу наступити апсолутно никакве сметње у саобраћају.

Како је код нас на свим пругама? [...] Никад сигурности иако је нова пруга, више кошта оправка и одржавање за две-три године него на овдашњим пругама што ће бити за 20 година. Врло чести прекиди саобраћаја. Тек се сад може видети како је неозбиљно грађена пруга Крушевац-Ужице (Атанацковић, Дневник: 138).

Уметнички интонирани и језичко-стилски ефектни сегменти Атанацковићевог дневника налазе се у својеврсним лирским интроспективним описима чежње за породицом и завичајем:

20. децембар 2017. године. - Непрестано мислим: па докле ће све ово трајати? Шта ми раде моји у Србији по овој великој зими и мразу? И трећи Божић хоће да проведу без мене. Две и по године, то су два и по века. Силна ме жудња мори за Драгом и децом, за нашом милом домовином, за мојим Ужицем и Ужичанима, где сам сила добра протурио и запамтио. Мој лепи породични живот. Мој дивни живот међу грађанима ужичким, са којима сам се вазда дичио и поносио, а и они ваљаде са мном. Сад одвојени, раздвојени, многи моји пријатељи помрли, многе море прогутало, а Бог једини зна ко ће се још жив вратити.

Те мисли ме обузму у овом великом Паризу, јер баш овде нема за мене ваздуха, нема за мене ни сласти ни задовољства, кад видим лепоту Париза како и она чами у мраку, суморна без светлости, како се нико сад честито не може огрејати, како се уметност ни лепота Париза не може осветлити, онда помислим: А шта је тек по нашој милој Србији? Како тамо народ живи? Шта рада

\footnotetext{
${ }^{6}$ Дневник Борисава Малише Атанацковића објављен је са подацима о његовом животу и друштвено-политичком анагажовању (в. Мисаиловић, 2006).
} 
моја Драга са својом и мојом децом? Имају ли хлеба? Имају ли с хлебом? Имају ли шта обући? Имају ли се са чим огрејати? О, Боже милостиви, хоће ли овоме бити краја? (Атанацковић, Дневник: 513).

Поменута три литерарно-документарна остварења ужичких писаца одликују се различитим типовима микродискурса, као што су нарација, дескрипција, аргументација, интерпретација. Захваљујући комбиновању различитих типова микродискурса, дневници, аутобиографије и мемоари омогућавају ученицима: (а) да унапређују логичко и критичко мишљење, да изграђују интелектуалну аутономију и стваралачки афинитет, да развијају истраживачки дух и културноисторијску свест; (б) да побољшавају читалачке компетенције - аналитичко читање и синтетичко уопштавање, рефлексију и евалуацију прочитаног, диференцијацију чињеница од њихове интерпретације, запажање значењских и стилских нијанси у тексту (в. Николић, 2020а).

Савремени дидактички концепт завичајности подразумева тежњу „да се школа врати животу и повеже са животом, да буде одраз живота и у служби живота”. „Истовремено, појам завичајности укључује и јединствени простор идентитетског упоришта, а завичајна култура је и мост према другим културама“ (Урошевић, Урошевић Хушак, 2012: 128). За наставу завичајне културе дају се следеће методичке препоруке: (а) текстове завичајне књижевности треба обрађивати применом савремених наставних система (корелацијско-интеграцијски, проблемско-стваралачки, компаративни и мултимедијални систем); (б) завичајну књижевност треба укључити у редовну наставу, додатну наставу и секције; (в) погодно је да се сусрет ученика са завичајном културом остварује и у ваннаставним активностима (в. Вељовић, 2018). Дакле, постоје различити начини којима се у завичајној настави могу обрадити мемоари Миладина Радовића, аутобиографија Маге Магазоновић и дневник Малише Атанацковића.

\section{Закључни осврт}

У завичајној култури ужичког краја постоји више стваралаца чија се литерарно-документарна проза може обрадити у оквиру редовне и додатне наставе или на ваннаставним активностима. Од текстова чији су аутори живели и стварали на размеђу 19. и 20. века издвајају се три жанровски различита примера литерарно-документарне завичајне прозе: (а) мемоари Миладина Радовића (1852-1915); (б) аутобиографија Марије Маге Магазиновић (1882-1968); (в) дневник Борисава Малише Атанацковића (1860-1919).

Литерарно-документарна проза завичајних писаца има висок образовни потенцијал јер представља наратив богат подацима и детаљима. Наставници матерњег језика и историје могу користити целовита дела или одломке како би на редовној или додатној настави живописно и динамично освет- 
лили догађаје, личности, појаве и процесе из прошлих епоха. Фактографска подлога у овим делима није сведена на статистичку збирку информација о прошлости него је дата из личне перспективе аутора које је био учесник или сведок догађаја, што помаже ученику да оживи догађаје у својој свести. Изабрани одломци из литерарно-документарне прозе пружају динамичне, сликовите и живописне наративе за млађе ученике, као и фактографски богатије текстове за старије ученике.

Литерарно-документарну завичајну прозу треба користити у настави завичајне културе: (1) за унапређивање вештина читања и разумевање; (2) за упознавање завичајне историје (политичке, друштвене, културне), као и улоге завичајних личности и догађаја у националној историји; (3) за стицање представа о начину на који се одвијао приватни живот (како је функционисала породица, каква је била организација школе и сл.). На овај начин код ученика се развија свест о припадности одређеној заједници и жеља да се личним деловањем допринесе очувању завичајне културне баштине.

\section{Извори}

Радовић, Мемоари: М. Радовић, Самоуки рукопис (Приредио: Слободан Радовић). Ужице: Народни музеј, 2006.

Магазиновић, Аутобиографија: М. Магазиновић, Мој живот (Приредила: Јелена Шантић). Београд: CLIO, 2000.

Атанацковић, Дневник: Б. М. Атанацковић, Дневник 1915-1919 (Приредио: Илија Мисаиловић). Ужице: Историјски архив, 2006.

\section{Литература}

Бењак, Љубешић, 2013: M. Benjak, M. Ljubešić, Od Peruška do otvorenog sustava. Zagreb: Školska knjiga.

Вељовић, 2018: Ј. Вељовић, Завичајна књижевност у савременом књижевном образовању (методички приступ). Београд: Учење и настава, IV/3, 499-512.

Елез, 2012: К. Elez, Pojmovno određenje zavičajne baštine, u: Zavičajna baština $i$ održivi razvoj. Split: Književni krug, 13-23.

Јоковић, 1998: М. Јоковић, Аутобиографско као документарно. Београд: Научни састанак слависта у Вукове дане, 27/1, 461-470.

Корићанац, 2000: Т. Корићанац, Марија Мага Магазиновић. Београд: Музеј града Београда.

Костић, 2012: Љ. Костић, Мемоари и аутобиографије као извор за реализацију васпитно-образовних циљева у основној школи, у: Настава и учење - циљеви, стандарди, исходи. Ужице: Учитељски факултет, 447-458. 
Костић, 2014: Љ. Костић, Етнографски записи у аутобиографији Мој живот Маге Магазиновић, у: Наука и савремени универзитет, Историографија и савременео друштво. Ниш: Филозофски факултет, 451-462.

Мисаиловић, 2006: И. Мисаиловић, О Борисаву Малиши Атанацковићу, у: Б. М. Атанацковић, Дневник 1915-1919. Ужице: Историјски архив, 679-797.

Николић, Вељовић, 2018: М. Николић, Б. Вељовић, Нарација и дескрипција у аутобиографији Марије Маге Магазиновић (лингвистички и методички аспект), у: Језик, култура, образовање. Ужице: Педагошки факултет, 125-136.

Николић, 2019: М. Николић, Мемоари Миладина Радовића у културној историји ужичког краја (језичко-стилске одлике), у: Живот посвећен трагању за етничким идентитетом, Зборник радова у част проф. Мијаху Миљи Радану. Темишвар: Филолошки, историјски и теолошки факултет Западног универзитета, 303-314.

Николић, 2020а: М. Николић, Зборник уметничких и научних остварења тематски обједињених око легенде о војводи Пријезди: образовни потенцијал (Небојша Лапчевић, Завет војводе Пријезде). Београд: Учење и настава, VI/1, 239-246.

Николић, 2020б: М. Николић, Новински текстови Марије Маге Магазиновић у листу „Политика” (рубрика „Женски свет”) из 1905. и 1906. године, у: Нa темељима народних говора, Зборник радова посвећен проф. Јордани Марковић. Ниш: Филозофски факултет, 469-482.

Радовић, 2006: С. Радовић, Поглед са Татинца - прилог биографији Миладина Радовића, у: М. Радовић, Самоуки рукопис. Ужице: Народни музеј, 7-14.

Скок, 1975: J. Skok, Princip zavičajnosti u nastavi književnosti u osnovnoj školi, u: Zavičajna književnost u nastavi. Žminj: Čakavski sabor, 59-70.

Стефановић, 2010: М. Стефановић, Аутобиографија. Београд: Службени гасник.

Тежак, 1980: S. Težak, Gramatika u osnovnoj školi. Zagreb: Školska knjiga.

Урошевић, Урошевић Хушак, 2012: N. Urošević, J. Urošević Hušak, Tematske rute u zavičajnoj nastavi - istarski književni itinereri. Pula: Metodički obzori, VII/3, $125-139$.

Цветковић, 2011: Н. Цветковић, Поетика завичаја и завичајности, језик и фолклор, у: Дијалекат - дијалекатска кюижевност. Лесковац: Лесковачки културни центар, 262-279. 
Milka V. Nikolić

\title{
DOCUMENTARY PROSE IN LITERATURE TAUGHT IN THE CLASSES OF HOMELAND CULTURE: USING THE WRITERS FORM UŽICE AS AN EXAMPLE
}

\begin{abstract}
Summary
Modern education prepares student for a life in the world where a dialogue between different cultures exists. On the other hand, modern education enables the growth of student's conscience about the belonging to a certain community and desire to personally contribute to preservation of homeland cultural heritage. It is believed that a child who is aware of the identity of its closer environment will have harsher criteria for accepting the legacies of general culture and understanding the separate cultures. Autobiographies, memoirs, and journals are characterized by different types of discourse (narration, description, argumentation, interpretation). The works in question (entire or in fragments) should be used as a didactic tool for developing and promoting students' different abilities. The paper discusses the educational potential of documentary prose in literature by the writers of different profiles (craftsmen, entrepreneurs, soldiers, artists), born in Užice, who depicted the social and private life from the end of the $19^{\text {th }}$ and the beginning of the $20^{\text {th }}$ century. The goal is to examine the possibilities for the development and improvement of students' abilities by using these works in history and literary classes. Documentary prose in literature by homeland writers represents the narrative rich in information and details, which allows teacher to enlighten the events, characters, and occurrences from different perspectives.
\end{abstract}

Key words: documentary prose in literature, Serbian language and literary classes, history classes, educational potential, homeland cultural heritage. 